International Journal of Current Advanced Research

ISSN: O: 2319-6475, ISSN: P: 2319 - 6505, Impact Factor: SJIF: 5.995

Available Online at www.journalijcar.org

Volume 6; Issue 3; March 2017; Page No. 2496-2499

DOI: http://dx.doi.org/10.24327/ijcar.2017.2499.0036

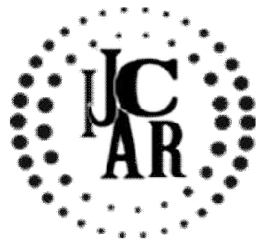

CASE REPORT

\title{
CRYSTALLIZING GALACTOCELE - HISTOPATHOLOGICAL DIAGNOSIS OF AN ENIGMATIC ENTITY
}

\author{
Radhika Yajaman Gurumurthy* and Nadig Siddharth Shankar
}

Consultant Pathologists, Bhagavan Pathology Laboratory, \#1116, $5^{\text {th }}$ Cross, 1503, Srirampet, Vinoba Road, Mysore - 570001

\section{A R T I C L E I N F O}

\section{Article History:}

Received $8^{\text {th }}$ December, 2016

Received in revised form $19^{\text {th }}$ January, 2017

Accepted $12^{\text {th }}$ February, 2017

Published online $28^{\text {th }}$ March, 2017

\section{Key words:}

Crystallizing Galactocele, Galactocele,

Benign Breast Diseases.

\begin{abstract}
A B S T R A C T
Galactocele is a benign cystic lesion occurring most commonly during pregnancy and lactational period. Sometimes the inspissated secretions within the galactocele undergo precipitation forming crystals. It is very essential to differentiate this condition from various benign and malignant conditions forming crystals. In this case report we describe the cytological and histopathological features of a very rare entity known as crystallizing galactocele. To the best of our knowledge this is the sixth reported case in English literature.
\end{abstract}

Copyright $@ 2017$ Radhika Yajaman Gurumurthy and Nadig Siddharth Shankar. This is an open access article distributed under the Creative Commons Attribution License, which permits unrestricted use, distribution, and reproduction in any medium, provided the original work is properly cited.

\section{INTRODUCTION}

Pregnancy produces many de novo breast masses as well as enlarges pre-existing breast masses. Most of the breast lesions in pregnant and postpartum patients are secondary to hormonal stimulation of the breast tissue. ${ }^{1}$ The differential diagnosis of the breast masses during pregnancy or postpartum period include galactocele, benign adenoma and very rarely carcinoma. ${ }^{2}$ Galactoceles are the most common benign breast lesions in pregnant and lactating women. ${ }^{3}$ In this case report we describe a rare case of crystallizing galactocele in a lactating woman which was diagnosed by histopathological examination of the lumpectomy specimen.

\section{Case Report}

A 27 year old lactating lady presented with a history of two painless lumps in right breast which were rapidly increasing in size. On examination, there were two discrete, mobile, nontender masses in right breast. The lumps were clinically diagnosed as fibroadenomas. On ultrasonography of the breast, two cystic lesions were noted. As the radiological diagnosis was inconclusive lumpectomy was done.

On gross examination, both lumps were grey-white, larger measuring $3 \times 3 \times 2 \mathrm{~cm}$ and smaller measuring $2 X 1.5 \times 1.5 \mathrm{~cm}$. Cut-section of both masses showed cystic spaces filled with whitish, soft, creamy material.

*Corresponding author: Radhika Yajaman Gurumurthy Consultant Pathologists, Bhagavan Pathology Laboratory, \#1116, 5th Cross, 1503, Srirampet,
Microscopic examination showed a cystic lesion lined by flattened epithelium. Adjacent breast tissue showed lactational changes.

Scrape smears were prepared from the whitish material within the cystic lesion and were stained with Giemsa, H\&E and papanicolaou stains. Smears showed numerous, distinct, compact, semi-transparent to blue coloured crystals of various sizes and shapes with well-defined borders. Few clusters of benign ductal epithelial cells showing lactational changes were also noted. Granular, amorphous, proteinaceous material admixed with frothy appearing lipid micelles were noted in the background.

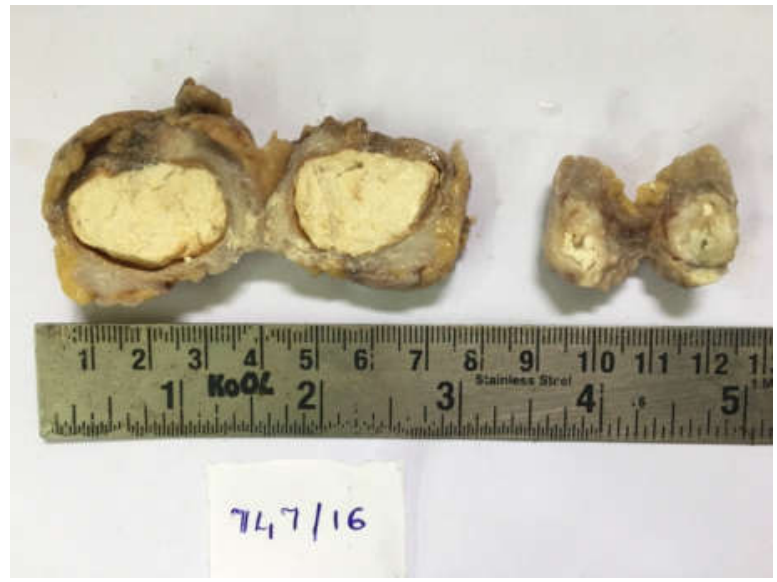

Figure 1 Cut-Surface Of The Breast Lump Showing Cystic Space Filled With Whitish Creamy Material. 

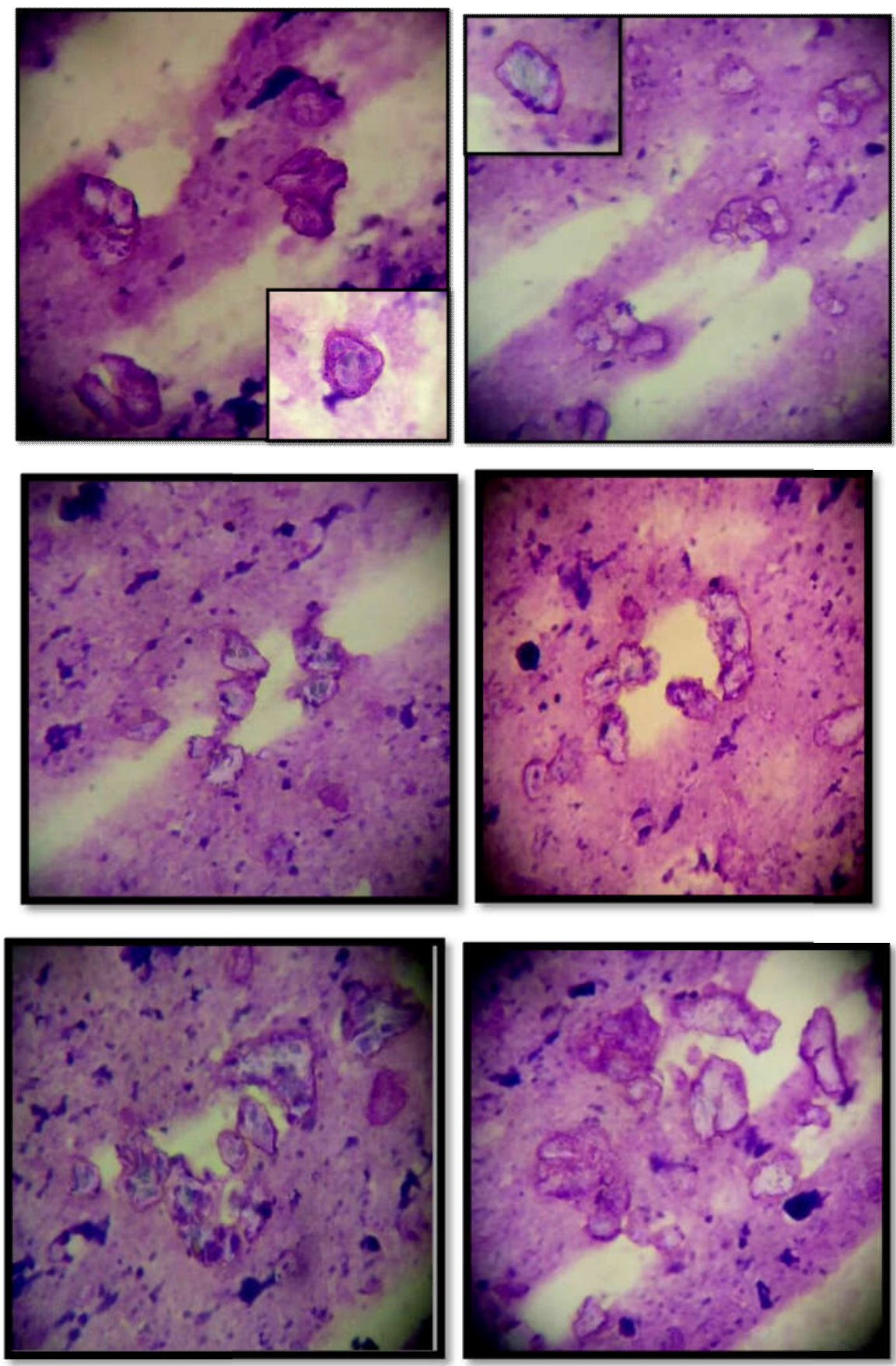

Figure 2A-F Scrape Smears: Many Distinct, Compact, Semi-Transparent To Blue Coloured Crystals Of Variable Shapes And Sizes Against A Proteinaceous Background.

\section{DISCUSSION}

Galactocele is a rare type of benign breast cyst. It is also known as "milk filled cyst". It is usually seen in pregnancy or in the setting of chronic galactorrhea caused by pituitary adenoma. ${ }^{4}$ However, some cases of galactocele have also been reported in male infant with hyperprolactenemia, ${ }^{5}$ accessory breast tissue in axilla, ${ }^{6}$ nulliparous woman with prolactinemia, ${ }^{7}$ postmenopausal woman ${ }^{8}$ and following augmentation mammoplasty. ${ }^{9}$

The major predisposing factors involved in the development of galactocele are: a secretory breast epithelium, the presence of prolactin stimulation, and some form of ductal obstruction. $^{10}$ In addition to lactation, several breast lesions which result in ductal obstruction such as inflammation, tumor and generalized conditions like breast surgery, transplacental passage of prolactin and oral contraceptives can also result in the development of galactocele. ${ }^{10,11}$

Galactoceles present as discrete, flocculent, painless, mobile masses of variable duration. The lump may be single or multiple, unilateral or bilateral. ${ }^{12}$ The most common location is subareolar region. ${ }^{12}$ Complications of galactoceles include difficulty in breast feeding, abscess formation and recurrence. $^{10}$

Galactoceles may sometimes mimic fibroadenoma or lactating adenoma clinically. ${ }^{12}$ As a result of hormonal stimulation, some malignant lesions enlarge during pregnancy and can be difficult to distinguish from galactocele. ${ }^{13}$

Radiologically it is difficult to distinguish a galactocele from breast abscess and carcinoma, as the features on ultrasound have overlapping appearences. ${ }^{14}$ Thus, the diagnosis of a 
galactocele is difficult to make on sonography alone, and a pathologic diagnosis is often warranted. ${ }^{10,11,15}$

FNAC of galactoceles yield milky fluid with various degrees of viscosity and the size of the mass reduces after aspiration. The smears show abundant secretory material with scattered foamy macrophages and occasional epithelial cells. ${ }^{1}$ FNAC is often considered to be both diagnostic and therapeutic in case of a galactocele. ${ }^{10}$

On gross inspection, a galactocele is composed of cysts that contain fluid contents resembling milk. Inspissated secretion may be present in the form of soft caseous material. Microscopically, they are lined by cuboidal or flat epithelial cells with cytoplasmic vacuolization owing to lipid accumulation. When intact, the cysts are encompassed by a fibrous wall of varying thickness, with little or no inflammatory reaction. ${ }^{16}$ The intraluminal secretions demonstrate positivity for acid and neutral mucins, lipids, lysozyme, albumin, Ig A secretory piece and whey protein. ${ }^{10}$

Sometimes, galactoceles undergo crystallization due to precipitation of inspissated lactational secretions that is mainly fat and proteins. There are many causes and possible mechanisms for the stimulation of precipitation and formation of crystals. It is a well known fact that the composition of human breast milk varies according to the individual, period of lactation, maternal age, parity, health and nutritional status, nationality, gestational age of the infant and even the right versus the left mammary gland. The aggregation or combination of any one of these factors may cause or initiate an imbalance in the breast milk components, resulting in precipitation. $^{10}$

Romanvsky stained cytological smears of crystallizing galactoceles show numerous, distinct, compact, semitransparent to dark blue/purple, refractile crystals with well-defined borders of variable shape and size. Background shows light blue, PAS-positive, granular, amorphous, proteinaceous material admixed with frothy-appearing lipid micelles. Crystals demonstrate intense positivity for PAS and weak positivity for calcium by the alizarin red $\mathrm{S}$ and von kossa technique. Papanicolaou staining results in homogenous, light green, washed out appearance of both the crystals and the proteinaceous and frothy background material. A detailed study of the properties of these crystals was done by Raso et al (1997). ${ }^{10}$

On scanning electron microscopy, crystals are discrete and demonstrate a variety of geometric shapes. The borders are sharp, often scalloped, and the surfaces are generally smooth. On transmission electron microscopy, crystals are in general electron lucent with well defined borders. The internal structure of the crystals display slight variations in electron density either in a swirling tigroid or reticulated fashion. On $\mathrm{X}$-ray diffraction, these crystals demonstrate no diffraction pattern. On electron probe microanalysis, crystals demonstrate small quantities of calcium, chlorine, potassium and sulphur. The crystals are well defined, angulated without periodicity or lattice formation. ${ }^{10}$

It is very essential to differentiate crystallizing galactocele from various benign and malignant lesions which produce crystals. Calcium phosphate crystals containing calcium and phosphorus are characteristically dark blue, nonbirefringent, von kossa and alizarin red $\mathrm{S}$ positive and are often associated with malignant breast epithelium. Calcium oxalate crystals containing calcium predominantly are, semitransparent to amber, refractile, birefringent, von kossa positive and alizarin red $\mathrm{S}$ negative and are usually associated with benign breast lesion. Gouty mammary tophi usually demonstrate, needle shaped, birefringent crystals associated with benign epithelial cells and multinucleated giant cells. Amyloid from primary breast amyloid tumor appears as homogeneous, irregular, metachromatic clumps of Diff-Quick . ${ }^{10}$

Galactoceles have a benign clinical course and are treatable lesions. They usually resolve without any treatment and no surgical treatment is needed. Therapeutic needle aspiration or surgical removal may be attempted if the tumor is enlarging. ${ }^{4}$ In the present case, lumpectomy was done as the mass was rapidly increasing in size and radiological examination was inconclusive.

\section{CONCLUSION}

Crystallizing galactocele is an unusual presentation of galactocele. It should be kept in mind as a differential diagnosis for breast lesions in pregnant and lactating women. To the best of our knowledge, this the sixth case reported after Raso et al (1997), Nikumbh et al (2013), Jyothi et al (2015), Nuzhat et al (2015), Shetty et al (2016). 10,15,17,18,19

\section{References}

1. Saad RS, Silverman JF. Breast. In: Bibbo M, Wilbur DC, editors. Comprehensive Cytopathology. $3^{\text {rd }}$ edition. Philadelphia: Saunders Elsevier; 2008. P. 713772 .

2. Koss LG, Melamed MR, editors. Koss' Diagnostic Cytology and its Histopathologic bases. $5^{\text {th }}$ Edition. Lippincott; 2006. P. 1082-1148.

3. Golden GT, Wangensteen SL. Galactocele of the breast. Am J Surg. 1972; 123(3): 271-3.

4. Sekhon S, Yadav AK. Galactocele Mimicking Malignancy: A Case Report. Rec Adv Path Lab Med. 2015; 1(3\&4): 9-11.

5. Paolo AT, Giuseppe F, Tiziana C et al. Persistent hyperprolactinemia and bilateral galactocele in a male infant. International Journal of Pediatric Endocrinology. 2009: 578-610.

6. Whang IY, Lee J, Kim KT. Galactocele as a changing axillary lump in a pregnant woman. Arch Gynecol Obstet. 2007; 76(4): 379-82.

7. Poiana C, Chirita C, Carsote $\mathrm{M}$ et al. Galactocele and prolactinoma-A pathogenic association?. Maturitas. 2009; 62(1): 98-102.

8. Dave PK, Bhaduri SB, Gupta S et al. Galactocele in a postmenopausal woman: A case report. Breast Cancer Res. 2000; 2(2): 53.

9. Tung A, Carr N. Postaugmentation galactocele: a case report and review of literature. Ann Plast Surg. 2011; 67(6): 668-70.

10. Raso DS, Greene WB, Silverman JF. Crystallizing galactocele: A case report. Acta Cytol. 1997; 41: $863-$ 70 .

11. Kline TS. Masquerades of malignancy: A review of 4241 aspirates from the breast. Acta Cytol. 1981; 25: $263-66$.

12. Kang O, Radswiki. Galactocele. Available from: http://radiopaedia.org/articles/galactocele. 
13. Son EJ, Oh KK, Kim EK. Pregnancy associated breast disease: Radiologic features and diagnostic dilemmas. Yonsei Med J.2006 Feb 28; 47(1): 34-42.

14. Sawhney $\mathrm{S}$ et al.Ultrasound separates galactoceles from simple cysts. Ultrasound reviews; $2002 \mathrm{Apr}$ 9.Available from: http://www.auntminnie.com/ index. aspx $? \mathrm{sec}=\mathrm{ser} \& \mathrm{sub}=\mathrm{def} \& \mathrm{pag}=\mathrm{dis} \& \mathrm{ItemID}=53045$.

15. Nikumbh DB, Desai SR, Shrigondekar PA et al. Crystallizing galactocele-An Unusual diagnosis on Fine needle Aspiration cytology. J Clin Diagn Res. 2013; 7(3): 604-5.
16. Rosen, Peter P, editors. Rosen's Breast Pathology. $3^{\text {rd }}$ edition. Lippincot Williams and Wilkins; 2009. P. 3470.

17. Jyothi K, Baliga V. Crystallizing Galactocele -A Cytological Dilemma: Case Report. Sch J App Med Sci.2015; 3(1B):129-30.

18. Nuzhat S, Qayoom S, Zubair Q et al. Old Crystallizing Galactocele - A Rare Case Report. J Cytol Histol. 2015; 6: 325-6.

19. Shetty A, Narasimha A, Jayalakshmi VJ. Crystallising Galactocele: Report of a rare variation. Breast disease. 2016; 36(2-3): 111-4.

\section{How to cite this article:}

Radhika Yajaman Gurumurthy and Nadig Siddharth Shankar (2017) ' Crystallizing Galactocele - Histopathological Diagnosis Of An Enigmatic Entity ', International Journal of Current Advanced Research, 06(03), pp. 2496-2499.

DOI: http://dx.doi.org/10.24327/ijcar.2017.2499.0036 